Article

\title{
An Evaluation of the Khubelu Wetland and Receiving Stream Water Quality for Community Use
}

\author{
Maeti George ${ }^{1,2, *(1)}$ and Veronica M. Ngole-Jeme ${ }^{1}$ \\ 1 Department of Environmental Science, School of Ecological and Human Sustainability, College of Agriculture \\ and Environmental Sciences, UNISA. Florida, Roodepoort 1710, South Africa; ngolevm@unisa.ac.za \\ 2 Department of Environmental Health, National University of Lesotho, Roma 180, Lesotho \\ * Correspondence: maetigeorge@gmail.com
}

Citation: George, M.; Ngole-Jeme, V.M. An Evaluation of the Khubelu Wetland and Receiving Stream Water Quality for Community Use. Water 2022, 14, 442. https://doi.org/ $10.3390 / w 14030442$

Academic Editor: Nikolaos Skoulikidis

Received: 6 December 2021

Accepted: 10 January 2022

Published: 1 February 2022

Publisher's Note: MDPI stays neutral with regard to jurisdictional claims in published maps and institutional affiliations.

Copyright: (C) 2022 by the authors. Licensee MDPI, Basel, Switzerland. This article is an open access article distributed under the terms and conditions of the Creative Commons Attribution (CC BY) license (https:// creativecommons.org/licenses/by/ $4.0 /)$.

\begin{abstract}
Wetlands in Lesotho are at the headwaters of some shared river basins like the OrangeSenqu River basin. These wetlands are threatened by various anthropogenic activities which are compromising their water quality. This study assessed the water quality status of the Khubelu wetland and stream using various water quality parameters to determine its suitability for domestic use, irrigation, and livestock watering. This was a preliminary research study on the suitability of the stream water for various uses in the study area. Calcium was the most concentrated cation in the stream $(8.20 \mathrm{mg} / \mathrm{L}$ to $16.8 \mathrm{mg} / \mathrm{L})$, followed by magnesium $(7.29 \mathrm{mg} / \mathrm{L}$ to $12.51 \mathrm{mg} / \mathrm{L})$, with sodium and potassium showing minimum values. The chemical oxygen demand values were in the range of 48 to $160 \mathrm{mg} / \mathrm{L}$. All parameters were within the EU and WHO ranges for drinking water, except EC, DO, BOD, COD, and $\mathrm{PO}_{4}$ levels. The Khubelu wetland water quality index (WQI) had a value of 93, whereas the stream WQI value was 107. The sodium Adsorption Ratio (SAR) values for the wetland and stream were 3.83 and 1.04, respectively, whereas the Soluble Sodium Percentage (SSP) ranged from 18.19 to $39.25 \%$. The stream water quality was acceptable for animal watering and crop irrigation, whereas wetland water would be acceptable for animal watering and would present some challenges for crop irrigation purposes due to the magnesium hazard it poses. The implications for the management of the wetland are discussed.
\end{abstract}

Keywords: animal grazing; soil structure; water quality; pollution reduction; water quality index; sodicity hazard; irrigation water

\section{Introduction}

Wetlands remain a vital ecosystem in areas where they are present because of the services they provide to the surrounding communities and the environment. When properly managed, wetlands act as sinks for contaminants including nutrients, sediments, and organic and inorganic compounds that have been transported to them from various sources [1]. They improve the quality of water, eliminating contaminants through various processes mediated by the vegetation and microbial populations they host [2-4]. Wetlands also act as storage for water, which they slowly release during periods of drought. An important aspect of wetlands is their closeness to other aquatic systems such as streams and lakes, which may serve as sources of potable water to the population. According to Seelig and DeKeyser [5], if a wetland is compromised, its ability to purify water and perform other ecosystem functions will eventually be affected.

Wetland ecosystems are challenged by the introduction of toxic substances originating from various anthropogenic activities, which contaminate wetland water and sediments, thereby compromising their ecological role. Anthropogenic activities which are likely to pollute wetlands include agriculture, sewage discharge, industrial effluent discharge, and animal grazing. Animal grazing contributes to wetland pollution primarily through the removal of vegetation cover, which results in accelerated erosion and affects the wetland's 
ability to reduce water velocity and to trap sediments onto which pollutants could be adsorbed. A high water velocity in wetlands has been associated with a short residence time of water in the wetland, a condition that hinders pollutant and sediment removal $[6,7]$ and denitrification in Ethiopia and China wetlands, respectively. Animal grazing may also destroy the soil structure through trampling, addition of nutrients-especially nitrates and phosphates from their excrement and urine-and introduction of hormones and other substances used to enhance animal production. In studies by Mereta [6] and Zhang et al. [8], it was observed that nutrient enrichment in streams promotes excessive growth of aquatic weeds and algal blooms, which could reduce dissolved oxygen (DO) concentration and increase the likelihood of eutrophication $[9,10]$. Livestock wastes also introduce organic matter, dissolved and suspended solids, and pathogenic bacteria such as E. coli, Salmonella species, and Giardia species into wetlands, degrading the quality of water in the wetland. A high grazing pressure could therefore be a major source of wetland degradation.

Lesotho is a country renowned for its relatively abundant freshwater of good quality. Palustrine wetlands in the highlands of the country sustain the supply of water of good quality to the kingdom and neighboring countries. These wetlands have sustained the Lesotho Highlands Water Project (LHWP) which serves Lesotho, South Africa, Namibia, and Botswana. Lesotho Water and Sanitation Policy ensures that there is a sustainable and integrated management of water resources [11]. However, there is uncontrolled animal grazing characterized by high stocking rates within the wetlands of the Kingdom. These wetlands are commonly utilized for grazing and watering of animals. With vegetation in the wetland flourishing even during winter when other pasture lands are dry, the wetlands are under continuous pressure from livestock grazing. The overgrazing problem is exacerbated by the overstocking of grazing animals, a situation that in Lesotho is culturally associated with wealth. These grazing activities go on despite the fact that the wetland and its surroundings are not a designated rangeland. The hydrological function of the wetlands as well as their water quality may be jeopardized if livestock grazing continues unregulated. The aim of the study was to evaluate the water quality of the Khubelu wetland and Khubelu stream in an endeavor to understand how anthropogenic activities in the wetland are affecting the wetland water. The study objectives were: (1) to analyze water for its suitability for human consumption, (2) to assess the suitability of wetland and stream water for crop irrigation, and (3) to assess the suitability of water for livestock drinking. The Water Quality Index (WQI) was used to evaluate the quality of water in the wetland. The Water Quality Index has been used to determine the suitability of water for different purposes [12-16]. This index was preferred because of its reliability as a tool for assessing water quality since it takes into consideration multiple water quality parameters $[17,18]$. The suitability of water for irrigation was assessed according to Richards [19,20], Suarez et al. [20], and Meireles et al. [21] using Electrical Conductivity (EC), Sodium Adsorption Ratio (SAR), sodium percent $(\mathrm{Na} \%)$, Soluble Sodium Percentage (SSP), and Magnesium Adsorption Rate (MAR). Various water parameters identified in different references for determining the suitability of water for animal watering were used to determine the suitability of water in the wetland and stream for animal consumption.

\section{Materials and Methods}

\subsection{Study Area}

The Khubelu wetland is situated within the Phapong sub-catchment, at the headwaters of the Senqu River and the Lesotho Highlands Water Project (LHWP) Phase II. The subcatchment is located at latitude $29^{\circ} 1^{\prime} 19.10^{\prime \prime} \mathrm{S}$ and longitude $28^{\circ} 52^{\prime} 26.01^{\prime \prime} \mathrm{E}$ (Figure 1). Lesotho climate is generally described as sub-humid to temperate cool, with warm and rainy summers and cool to cold dry winters. The mean minimum temperature of $0{ }^{\circ} \mathrm{C}$ occurs in June, which is the coldest month in winter [22]. The monthly mean temperatures in the lowlands range from -3 to $-1{ }^{\circ} \mathrm{C}$ in winter, whereas the highlands record temperatures from -8.5 to $-6{ }^{\circ} \mathrm{C}$, with monthly mean winter minimum extremes of $-10^{\circ} \mathrm{C}$ and daily minimum values of $-21{ }^{\circ} \mathrm{C}$ in the same season [22]. January is the hottest month with $32{ }^{\circ} \mathrm{C}$ 
in the lowlands and $20^{\circ} \mathrm{C}$ in the highlands, with a maximum of $34{ }^{\circ} \mathrm{C}$ in the lowlands and $24^{\circ} \mathrm{C}$ in the highlands [22]. Lesotho has three sub-basin river systems, namely, Mohokare, Makhaleng, and Senqu. Senqu drains two-thirds of the country, originating in the extreme north of the country (study area) and leaving Lesotho near the South-Western area. Lesotho has three wetland systems, i.e., palustrine, riverine, and lacustrine wetlands. Palustrine wetlands are mainly found in the highlands of the country, which are high-precipitation areas.

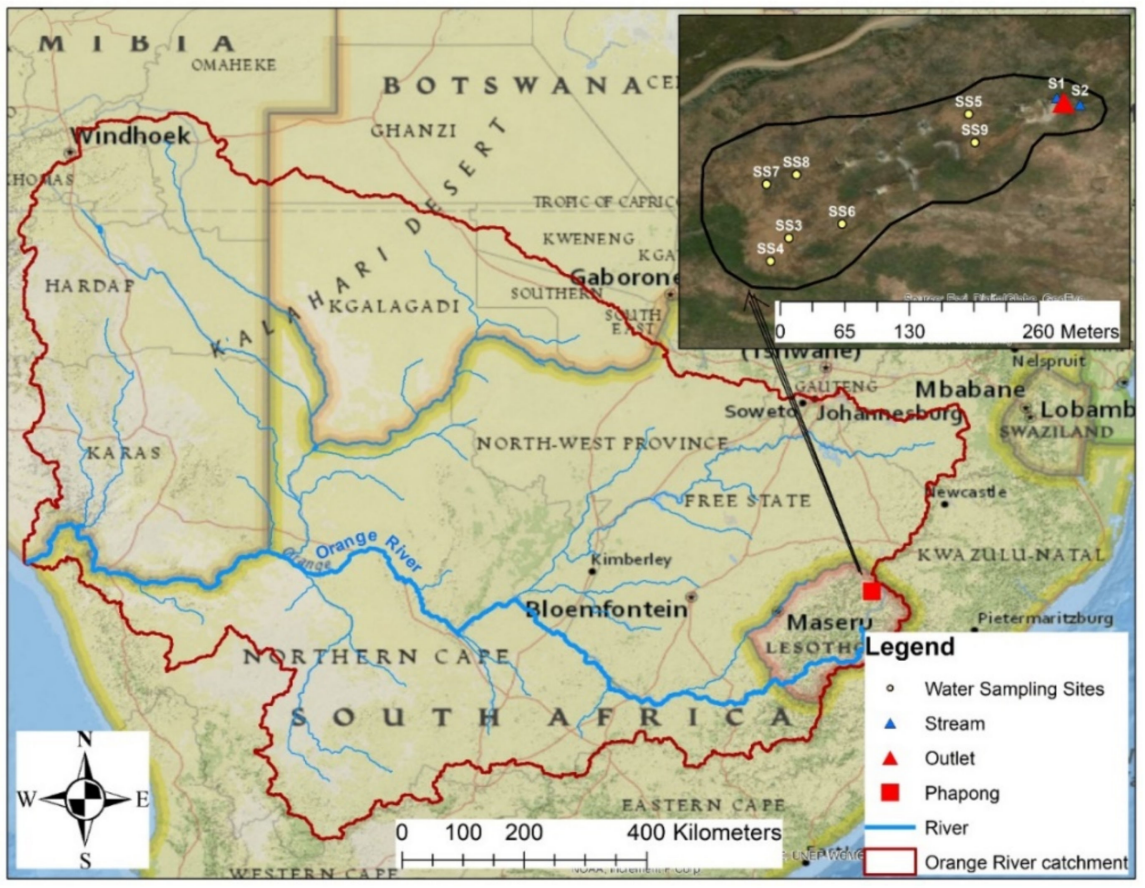

Figure 1. Location of the Khubelu wetland within the Phapong sub-catchment, showing wetland sampling sites and stream sampling sites.

The study area is characterized by basaltic parent material, which, due to poor development, makes soil prone to erosion. The wetland therefore does not have an efficient water holding capacity [23]. The water that is discharged into the stream by the Khubelu wetland is widely used by local communities for animal grazing and watering [24] and has a potential for crop irrigation by downstream users.

\subsection{Water Sampling}

Water sampling points were located upstream (SS3, SS4, SS7), midstream (SS6, SS8), and downstream (SS5, SS9) of the wetland (Figure 1). Piezometers were installed at each of these sampling points, enabling the identification of any trend in water quality parameters at the point of water entry into the wetland, within the wetland, and at the point of water exit from the wetland into the stream. Two additional sampling points (S1 and S2 with GPS coordinates $29^{\circ} 01^{\prime} 18.40^{\prime \prime} \mathrm{S}, 028^{\circ} 52^{\prime} 24.88^{\prime \prime} \mathrm{E}$ and $29^{\circ} 01^{\prime} 18.62^{\prime \prime} \mathrm{S} 028^{\circ} 52^{\prime} 25.64^{\prime \prime} \mathrm{E}$, respectively) (Figure 1) were located within the Khubelu stream into which the wetland empties, to determine the quality of the water delivered by the wetland into the stream. A total of nine sampling points were therefore considered in this study. Water sampling from all nine sites was done monthly over a period of 1 year. Hydrologically, the months from June to September are dry months, from March to May are mid-wet months, and from October to February are wet months. There was no water sampling between June and August, since these months fall within the dry season, and there was no groundwater and surface water in the wetland and the stream, respectively. This period also coincides with the dry season in the study area. The $\mathrm{pH}$, electrical conductivity (EC), and amount of dissolved oxygen (DO) of the water samples were measured in situ using a $\mathrm{pH}$ meter model HI 8424, a conductivity meter model HI 8033, and a DO meter model HI 9142, respectively. 
Water samples were collected in $2 \mathrm{~L}$ polyethylene bottles, acidified, and stored at $4{ }^{\circ} \mathrm{C}$ until analyzed [25].

\subsection{Water Analysis}

The water quality parameters determined in this study were $\mathrm{pH}, \mathrm{EC}, \mathrm{DO}$, Biochemical Oxygen Demand (BOD), Chemical Oxygen Demand (COD), Total Dissolved Solids (TDS), nitrates $\left(\mathrm{NO}_{3}\right)$, phosphates $\left(\mathrm{PO}_{4}\right)$, calcium, magnesium, potassium, sodium, and chlorides $(\mathrm{Cl})$. These parameters were selected because they have been widely used to assess the suitability of water for various purposes [26-28], and some, such as BOD, COD, nitrates, and phosphates, have been used as indicators of organic [29] and nutrient pollution [30]. The standard method $5210 \mathrm{~B} 5$-day-biological oxygen demand $\left(\mathrm{BOD}_{5}\right)$ test recommended by APHA [25] — was used to determine the $\mathrm{BOD}_{5}$ of the samples. Total dissolved solids analysis was done gravimetrically. Phosphate concentration in the water samples was analyzed using the molybdenum blue method according to STN EN ISO 6878 (75 7465) [31]. Nitrate content in the samples was determined through colorimetric Brucine method [25]. Chlorides in water were determined by titration of the water against a silver nitrate solution [25]. Analysis of $\mathrm{Ca}, \mathrm{K}, \mathrm{Mg}$, and $\mathrm{Na}$ in the water samples was done by use of the flame Atomic Absorption Spectrometry (AAS) AAnalyst 200 Perkin Elmer. For the determination of COD in water samples, potassium dichromate was added to heated $\mathrm{H}_{2} \mathrm{SO}_{4}$ medium for $2 \mathrm{~h}$ using a HACH COD reactor, after which the mixture was cooled and then added to the water sample, and the rest of the procedure was as described in APHA [25]. Readings were taken using a HACH (model DR-2000) spectrophotometer.

\subsection{Quality Assurance Measures}

Prior to sampling, each polyethylene bottle was washed with a metal-free detergent and then rinsed with distilled water. The bottles were then soaked in 10\% nitric acid for $24 \mathrm{~h}$, after which they were rinsed twice with distilled water. At the sampling site, the bottles were rinsed with the wetland water before sampling. Instrument calibration was performed using approved standards, whereas equipment setup followed the manufacturer's guidelines. AnalaR chemicals were used for all analyses. All water samples were analyzed in triplicate, and the mean values of the three readings were reported as the final results.

\subsection{Data Analysis}

Data obtained from the analyses of the 13 parameters were subjected to One-Way Analysis of Variance (ANOVA) with Tukey's Kramer Post Hoc test to determine whether the differences observed in the quality of water taken upstream to downstream of the wetland and from the wetland to the stream were significant. The suitability of the wetland and stream water for human consumption was determined using the Water Quality Index (WQI), as indicated in Equation (1) proposed by Curtis [32] and Pathak et al. [33]

$$
\mathrm{WQI}=\frac{\sum \mathrm{Wn} \mathrm{qn}}{\sum \mathrm{Wn}}
$$

where WQI = Water Quality Index, $\mathrm{n}=$ number of water quality parameters, qn = quality rating, of the 13th water quality parameter, $\mathrm{Wn}=$ relative weight, of the 13th parameter.

The values for Quality rating (qn) and Relative weight (Wn) in Equation (1) were determined according to Equations (2) and (3), respectively:

$$
\text { qn }=\{[(\text { Vactual }- \text { Videal }) /(\text { Vstandard }- \text { Videal })] \times 100\}
$$

where qn = Quality rating of the 13th water quality parameter, Vactual = Actual value of the water quality parameter obtained from laboratory analysis, Videal = Ideal value of those water quality parameter that are assumed to be zero for drinking water, except $\mathrm{pH}$ 
with a value of 7.0, and DO with a value of $14.6 \mathrm{mg} / \mathrm{L}$, Vstandard = Recommended WHO standard of the water quality parameter.

$$
\mathrm{Wn}=\mathrm{I} / \mathrm{Sn}
$$

where $\mathrm{Wn}=$ Relative weight of the 13th parameter, $\mathrm{Sn}=$ Standard permissible value for the 13th parameter, I = Proportionality constant.

A weighted arithmetic mean of the parameters were used in the calculation of WQI index, and the Mishra and Patel [34] classification method was used to classify the water as excellent (WQI = 0-25), good (WQI = 26-50), poor (WQI = 51-75), very poor $(\mathrm{WQI}=76-100)$, and unsuitable for drinking (WQI > 100). The water quality was also compared with WHO water quality for domestic use.

The water in both the stream and the wetland were also assessed for their suitability for crop irrigation using the international standards for irrigation. We used the method for assessing the suitability of water for irrigation described by Richards [19], Suarez et al. [20], and Meireles et al. [21], based on the values of EC, Sodium Adsorption Ratio (SAR), $\mathrm{Na} \%$, Soluble Sodium Percentage (SSP), and Magnesium Adsorption Rate (MAR). The Sodium absorption ratio was used to assess the sodium toxicity of the water and was calculated according to Equation (4) $[19,20]$. Soluble Sodium Percentage and sodium risk were calculated as shown in Equations (5) and $(6)[19,35]$, whereas MAR was calculated using Equation (7) [36,37].

$$
\begin{gathered}
\left.\mathrm{SAR}=\left[\mathrm{Na}^{+}+/ \sqrt{\left(\mathrm{Ca}^{2+}+\mathrm{Mg}^{2+}\right.}\right) / 2\right] \\
\mathrm{SSP}=\frac{\mathrm{Na}^{+}}{\mathrm{Na}^{+}+\mathrm{K}^{+}+\mathrm{Ca}^{2+}+\mathrm{Mg}^{2+}} \times 100 \\
\mathrm{Na} \%=\frac{\left(\mathrm{Na}^{+}+\mathrm{K}^{+}\right) \times 100}{\mathrm{Na}^{+}+\mathrm{K}^{+}+\mathrm{Ca}^{2+}+\mathrm{Mg}^{2+}} \\
\mathrm{MAR}=\frac{\mathrm{Mg}^{2+}}{\mathrm{Ca}^{2+}+\mathrm{Mg}^{2+}} \times 100
\end{gathered}
$$

Considering that the wetland is also used for animal grazing, the suitability of the water for animal grazing was determined by comparing the mean values of the various water parameters with the permissible limits for these parameters from different references, in relation to watering animals. Among the parameters used for this purpose were $\mathrm{pH}$, nitrates, chlorides, and salinity, as determined by total dissolved salts.

\section{Results and Discussion}

\subsection{Properties of Water in the Wetland and Stream}

The mean $\mathrm{pH}$ values varied from 6.32 to $7.11 \mathrm{pH}$ in water samples from the wetland and from 6.67 to $7.69 \mathrm{pH}$ in samples from the stream (Table 1), indicating that water in both the wetland and the stream had circumneutral $\mathrm{pH}$ values. The $\mathrm{pH}$ appeared to be within the acceptable WHO and EU limit of 6.5-8.5 $\mathrm{pH}$ for human consumption. For livestock watering, $\mathrm{pH}$ ranges of 6.5-8.5 $\mathrm{pH}$ [38] and 5.5-9.0 $\mathrm{pH}$ [39] are acceptable. The Food and Agricultural Organisation's (FAO) allowable $\mathrm{pH}$ for crop irrigation is $6.0-8.5 \mathrm{pH}$, whereas the South Africa irrigation water quality standards $\mathrm{pH}$ range is 6.5 to 8.4 . The $\mathrm{pH}$ values of the water in the stream and wetland fell within the acceptable range for livestock watering and crop irrigation. 
Table 1. Physicochemical and nutrient parameters of stream and wetland water (Mean \pm Standard Deviation).

\begin{tabular}{ccccccc}
\hline \multirow{2}{*}{ Parameter } & \multicolumn{3}{c}{ Wetland } & \multicolumn{3}{c}{ Stream } \\
\cline { 2 - 7 } & Min & Max & Mean & Min & Max & Mean \\
\hline $\mathrm{pH}$ & 6.32 & 7.11 & $6.59 \pm 0.37$ & 6.67 & 7.69 & $6.95 \pm 0.42$ \\
\hline $\mathrm{EC}(\mathrm{mS} / \mathrm{cm})$ & 0.41 & 1.12 & $0.75 \pm 0.29$ & 0.67 & 2.11 & $1.21 \pm 0.67$ \\
\hline $\mathrm{DO}(\mathrm{mg} / \mathrm{L})$ & 0.75 & 1.79 & $1.41 \pm 0.46$ & 2.33 & 4.97 & $4.06 \pm 1.07$ \\
\hline $\mathrm{Ca}(\mathrm{mg} / \mathrm{L})$ & 5.42 & 7.55 & $6.25 \pm 1.03$ & 8.2 & 16.8 & $13.24 \pm 3.17$ \\
\hline $\mathrm{Na}(\mathrm{mg} / \mathrm{L})$ & 5.01 & 13.25 & $10.68 \pm 3.82$ & 3.17 & 6.23 & $4.74 \pm 1.18$ \\
\hline $\mathrm{Mg}(\mathrm{mg} / \mathrm{L})$ & 8.36 & 10.75 & $9.42 \pm 1.02$ & 7.29 & 14.45 & $11.32 \pm 2.62$ \\
\hline $\mathrm{K}(\mathrm{mg} / \mathrm{L})$ & 0.08 & 4.8 & $2.96 \pm 2.10$ & 0.19 & 1.81 & $0.74 \pm 0.73$ \\
\hline $\mathrm{TDS}(\mathrm{mg} / \mathrm{L})$ & 189 & 463.5 & $277.80 \pm 125.29$ & 45 & 314 & $151.60 \pm 101.61$ \\
\hline $\mathrm{NO}{ }_{3}(\mathrm{mg} / \mathrm{L})$ & 8.16 & 9.96 & $8.76 \pm 0.84$ & 7.01 & 13.03 & $10.03 \pm 2.22$ \\
\hline $\mathrm{PO}(\mathrm{mg} / \mathrm{L})$ & 0.17 & 0.61 & $0.33 \pm 0.19$ & 0.06 & 1.26 & $0.53 \pm 0.47$ \\
\hline $\mathrm{BOD}(\mathrm{mg} / \mathrm{L})$ & 1.47 & 3.92 & $2.51 \pm 1.03$ & 1.02 & 6.92 & $4.06 \pm 2.22$ \\
\hline $\mathrm{COD}(\mathrm{mg} / \mathrm{L})$ & 48 & 140.8 & $108.44 \pm 42.69$ & 10 & 55 & $36.70 \pm 16.48$ \\
\hline $\mathrm{Cl}(\mathrm{mg} / \mathrm{L})$ & 35.3 & 68.9 & $52.38 \pm 14.26$ & 28.86 & 58 & $46.62 \pm 12.02$ \\
\hline
\end{tabular}

The EC values for all samples were less than $3 \mathrm{mS} / \mathrm{cm}$, with the values for the water samples from the stream being slightly higher than those from the wetland samples (Table 1). The results from ANOVA, however, showed an insignificant difference between the EC values of the water samples from the wetland and those of the stream samples $(p=0.42)$. The maximum EC recorded in the stream was $2.11 \mathrm{mS} / \mathrm{cm}$ (Table 1), which was above the WHO permissible level of $1.5 \mathrm{mS} / \mathrm{cm}$ for drinking water. Electrical conductivity values below $1.5 \mathrm{mS} / \mathrm{cm}$ are classified as excellent and those in the range of $1.5-5.0 \mathrm{mS} / \mathrm{cm}$ as very satisfactory according to FAO standards for livestock drinking.

However, the EC levels were higher than the threshold of $0.4 \mathrm{mS} / \mathrm{cm}$ for irrigation [40], indicating some risk for crops downstream of the wetland, but stream TDS was within the permissible level of $450 \mathrm{mg} / \mathrm{L}$ for irrigation [41]. High conductivity has been associated with salinity, which could be due to high levels of phosphates, sulphates, chlorides, and nitrogen in the water samples [42,43]. These nutrients are usually present in animal fecal matter and might have been found in the examined region, originated from animal droppings, since the area is used for grazing purposes. However, $\mathrm{NO}_{3}$ levels were below $5 \mathrm{mg} / \mathrm{L}$, within the acceptable range for irrigation [41].

Dissolved oxygen levels ranged from 0.75 to $1.79 \mathrm{mg} / \mathrm{L}$ in the wetland and from 2.33 to $4.97 \mathrm{mg} / \mathrm{L}$ in the stream, with all values being below the WHO requirement of $5 \mathrm{mg} / \mathrm{L}$ in both the wetland and the stream water samples (Table 1). Dissolved Oxygen is usually a measure of organic and nutrient pollution in water [44]. The low DO values obtained for the water samples in this study could be reflecting some degree of chemical and/or organic pollution. Dissolved oxygen concentrations within the wetland were significantly lower than those in the stream $(p=0.003)$, which could have been caused by several factors. Piezometers are devices that do not allow for aeration of the water samples; hence, this may have contributed to a reduction in the amount of dissolved oxygen in the water samples. In addition, the organic matter content in wetlands is usually high, but in the Khubelu wetland, the amount of OM could have been increased by droppings from animals grazing in the wetland. The high biological activity associated with the decomposition of organic matter could also have resulted in low DO levels in the wetland water. These results are supported by the findings of Mason et al. [45], who also found low DO in organic matter-rich streams. However, self-purification of streams through aeration could have contributed to increased DO in the stream (from the lowest wetland value of $0.75 \mathrm{mg} / \mathrm{L}$ to the lowest stream value of $2.33 \mathrm{mg} / \mathrm{L}$ ). 
Though the amount of DO in the wetland and stream was low, the BOD values were not very high, as shown in Table 1, except for a few sites which had BOD values above the acceptable WHO limit of $5 \mathrm{mg} / \mathrm{L}$ for drinking water. The values for biological oxygen demand in the wetland showed an insignificant difference from those of the stream $(p=0.15)$. Chemical oxygen demand levels in the water samples were above the WHO standard of $10 \mathrm{mg} / \mathrm{L}$ for drinking water for both the stream and the wetland (Table 1). The level of COD observed in the wetland could be associated with a high level of chemical pollution originating from various anthropogenic activities including grazing in the wetland. Oyem et al. [46] made a similar observation in Agbor Nigeria.

The mean concentrations of $\mathrm{Ca}$ and $\mathrm{Mg}$ were higher in water from the stream compared to water from the wetland, whereas $\mathrm{Na}$ and $\mathrm{K}$ levels were higher in the wetland water compared to the stream water (Table 1). All the values were within the EU and WHO drinking water standards (which are also similar), as well as the FAO water standards for animal consumption. Magnesium concentration was below the FAO limit of $500 \mathrm{mg} / \mathrm{L}$ for consumption by sheep, posing no threat to these animals. The values of nitrates in all samples were within the ranges of the WHO standards for drinking water (Table 1). Phosphate levels in samples from the wetland were significantly different from those in the stream water samples $(p<0.01)$. Possible sources of phosphates in the wetland could be phosphate-rich animal waste. The excessive removal of vegetation by animal overgrazing, coupled with poor vegetation cover, could also have subsequently affected plant phosphate uptake and assimilation, increasing the phosphate amount available for leaching into the wetland [47]. The stream phosphate level agreed with the level of $1.07 \mathrm{mg} / \mathrm{L}$ obtained by Mots'ets'e et al. [48] for Khalong-La-Lithunya wetlands in Lesotho.

\subsection{Spatial Variation of Water Quality Parameters}

There was no variation of $\mathrm{pH}$ values in water samples taken upstream to downstream of the wetland $(p=0.25)$. $\mathrm{pH}$ had a positive correlation with $\mathrm{NO}_{3}$ levels $(\mathrm{r}=0.683)$, owing to the increase in the rate of nitrification in alkaline conditions and a likelihood of nitrogen removal from the wetland. Electrical conductivity values in wetland midstream water samples were higher than the values from wetland upstream and downstream samples (Figure 2); however, the ANOVA results indicated that these differences were insignificant $(p=0.78)$. A moderate correlation between EC and $\mathrm{Ca}(\mathrm{r}=0.610)$ and $\mathrm{Mg}(\mathrm{r}=0.532)$ might imply Ca- and Mg-induced salinity of the wetland water. Total dissolved solids levels fluctuated within the wetland, being higher midstream than in other sections and increasing in the stream (Figure 2). There was a strong positive correlation between TDS and K $(\mathrm{r}=0.785)$ and $\mathrm{Na}(\mathrm{r}=0.634)$, implying external sources of the two cations that significantly contributed to the wetland TDS. A significant inverse correlation between TDS and DO ( $r=-0.599)$ might imply eutrophic conditions [49], since some level of dissolved organic matter may constitute to TDS. Furthermore, a negative correlation between DO and COD $(r=-0.732)$ revealed a possibility of organic pollution that depleted DO. The patterns of $\mathrm{DO}$ and BOD for wetland water samples from upstream to downstream were similar, with no clear pattern observed and no significant differences noted $(p=0.37)$. The values for both followed the pattern stream values $>$ downstream values $>$ upstream values $>$ midstream values (Figure 2). The pattern of COD in the water samples was however different, as COD values in wetland water samples steadily increased from upstream to downstream, $(p<0.01)$, but dropped significantly in water samples from the stream (Figure 1). Studies by Kistemann et al. [42] found lower DO downstream of wetlands with animal grazing than upstream, which Kato et al. [43] associated with high levels of nutrients downstream and the consequent depletion of available oxygen. The increase in BOD from midstream to downstream could be attributed to an increase in organic pollution downstream of the wetland. A positive correlation existed between $\mathrm{PO}_{4}$ levels and $\mathrm{EC}(\mathrm{r}=0.749)$ and BOD $(r=0.655)$, and this points to DO depletion through nutrient pollution. This explains the unsuitability of the water quality in the stream for human consumption. However, 
despite the increasing downstream organic pollution as indicated by the BOD values, crop irrigation and animal drinking would not be affected.
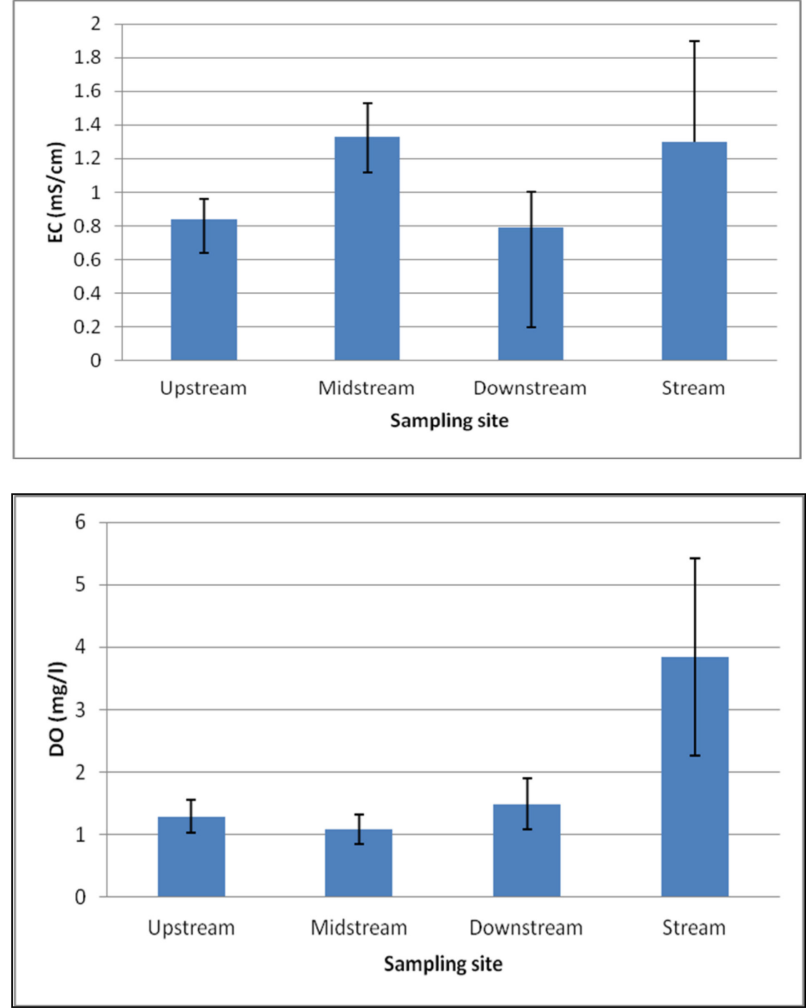
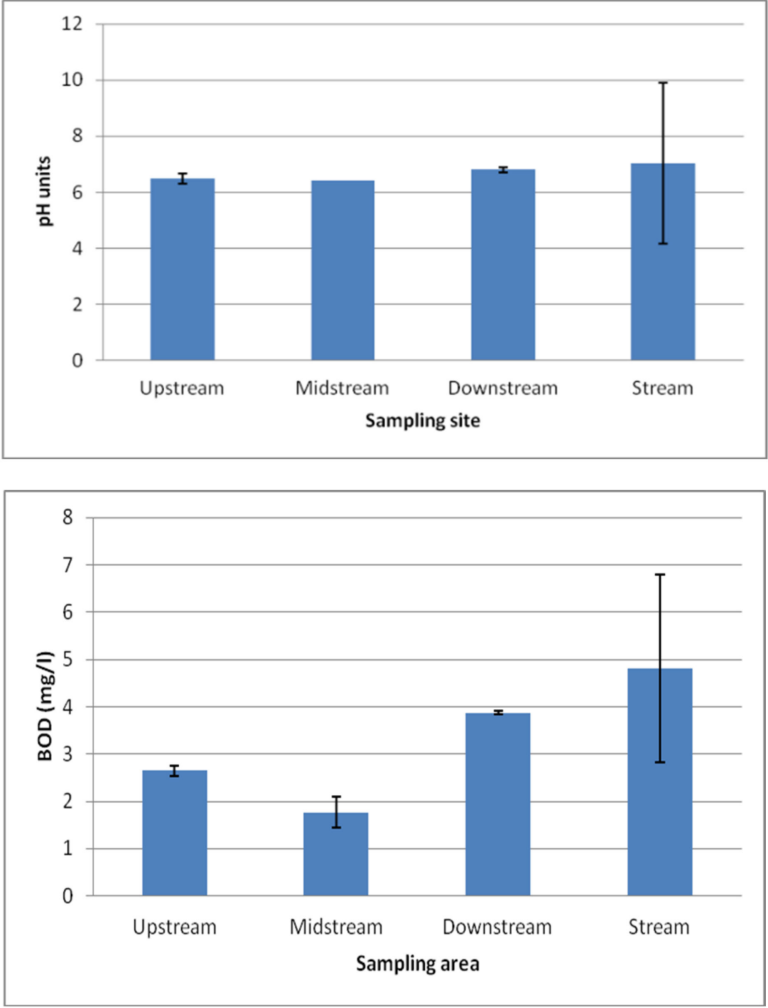

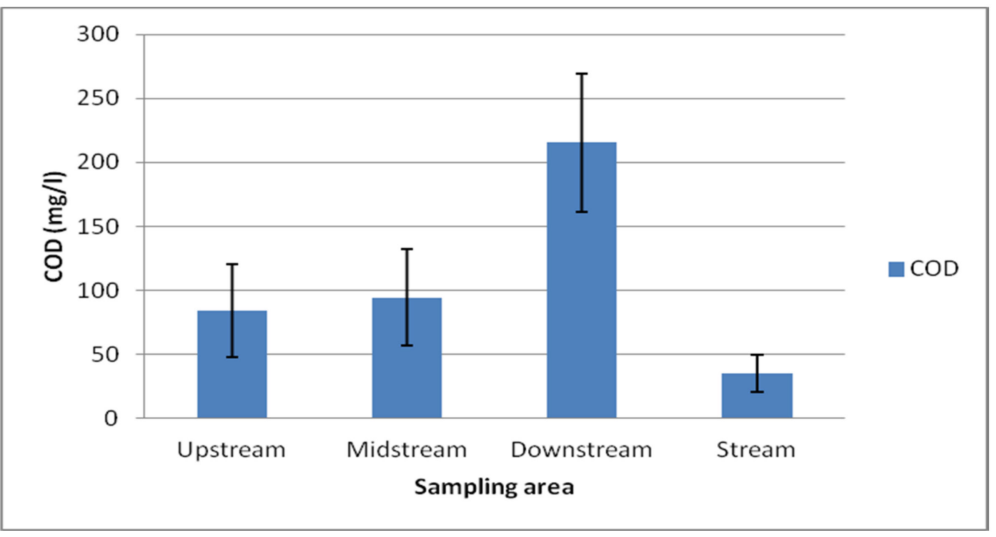

Figure 2. Averages of water quality parameters upstream to downstream of the wetland and the stream.

The sodium and potassium levels in wetland water samples increased from upstream to downstream, whereas no pattern was observed for $\mathrm{Mg}$ and Ca concentrations (Figure 3). Calcium and magnesium levels increased while reaching the stream. However, all mineral levels pose no threat to water quality within the wetland. As a result, water use for animal drinking is not likely to be impacted negatively by these cations. Nitrates levels showed an increasing trend from upstream to downstream, even though the difference was insignificant $(p=0.21)$, but decreased as the wetland drained into the stream. High nitrates level midstream and downstream of the wetland might be signs of the wetland being unable to reduce the nitrates levels. Animal excreta could be another source of nitrates within the wetland. However, low levels of $\mathrm{NO}_{3}$ in the stream might be a result of its mineralization by wetland soil and assimilation into biomass. Similar observations were made by Thorslund et al. [4]. 

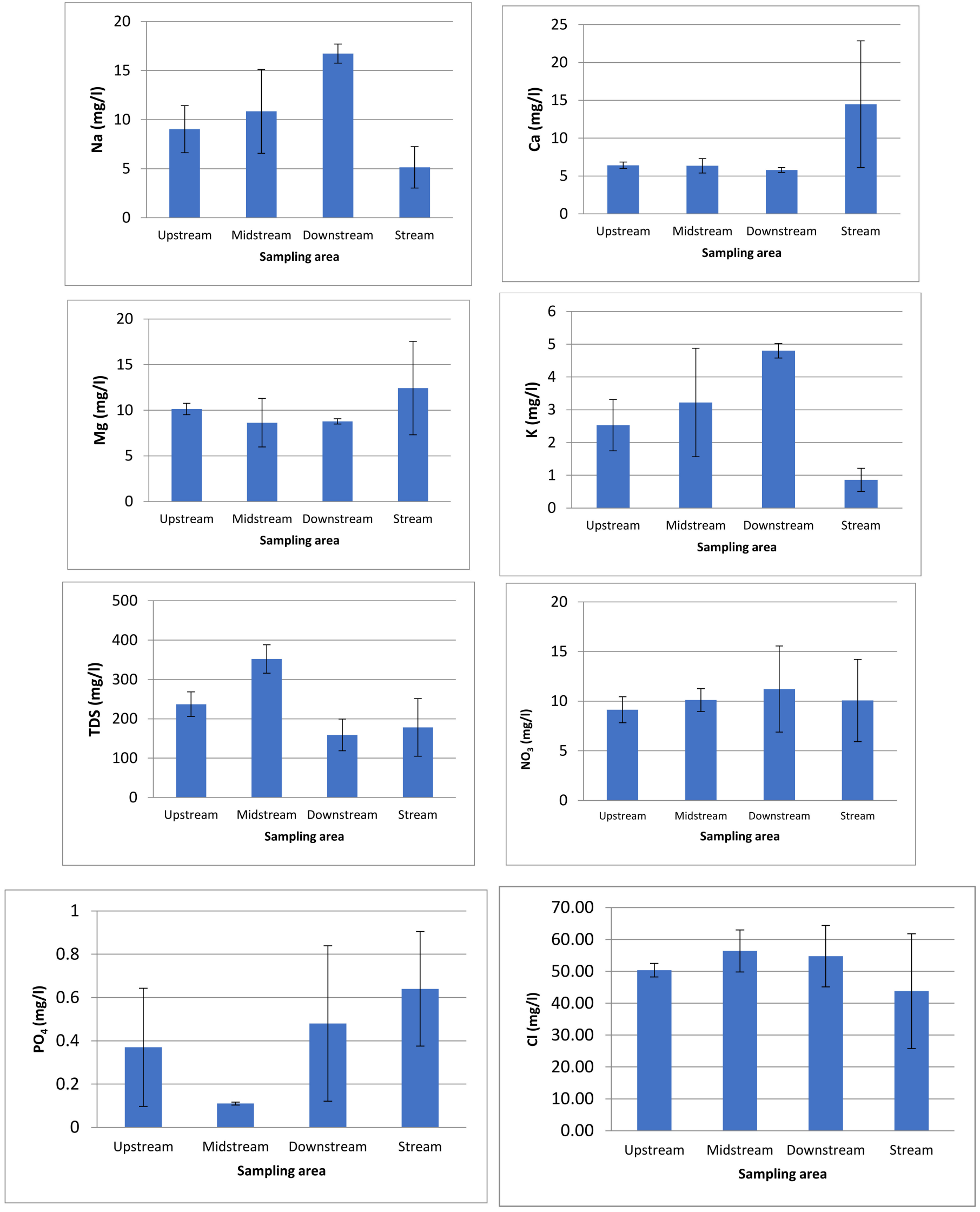

Figure 3. Averages of nutrient content upstream, midstream, and downstream of the wetland, as well as the Khubelu stream. 
A fluctuating trend was observed for phosphates, from upstream to downstream of the wetland, with highest $\mathrm{PO}_{4}{ }^{3-}$ levels in the wetland recorded downstream (Figure 3). However, the differences in these levels were insignificant $(p=0.07)$. The stream had a higher phosphate level than the wetland, which could threaten the stream water quality through nutrient pollution [50]. In a study by Hubbard et al. [51], a high nutrient concentration was associated with a direct input by animals during grazing, when compared to other land uses like arable land. There might also be an external source of phosphates, which may be associated with the decomposition of plant material and its leaching from the soil [52] into the stream. A high nutrient concentration in the stream would lead to poor water quality through DO depletion, eutrophication, and algal blooms.

\subsection{Water Quality Index of the Wetland and Stream for Human Consumption}

A WQI of 93 was determined for the wetland and a value of 107 for the stream which, according to Mishra and Patel [34] and Pathak et al. [33], indicate "very poor" and "unsuitable for drinking" water, respectively. The poor water quality of the wetland and stream might be due to $\mathrm{EC}, \mathrm{DO}, \mathrm{PO}_{4}, \mathrm{BOD}$, and COD levels in the stream and wetland, which fell outside the range of maximum acceptable limits specified by the WHO for domestic use. Across the wetland from upstream to downstream, WQI of 93, 61, and 90 were recorded, and water was graded as very poor, poor, and very poor, respectively [34]. These WQI values indicate that the water quality is better midstream than upstream and downstream of the wetland. The water from both the wetland and the stream is, however, not safe for domestic use by communities and has to be treated prior to utilization. Being one of the tributaries of the Orange Senqu catchment, the Khubelu stream may be discharging water of poor quality into the Senqu River, jeopardizing the overall water provision to the riparian states (South Africa, Namibia, and Botswana).

\subsection{Sodicity Hazard of the Water in the Wetland and Khubelu Stream}

The quality of irrigation water is assessed based on the salinity and toxicity risk posed by the water to vegetation [53]. The mean values for $\mathrm{Na} \%$ were 46.50 and 29.04 for the wetland and stream, respectively (Table 2). A sodium percentage that is less than 20 is classified as excellent, in the range of 20-40 as good, between 40 and 60 as permissible, between 60 and 80 as doubtful, and $>80$ as unsuitable for water use in crop irrigation [54]. Water from the wetland was therefore classified as permissible (40-60) for irrigation, whereas stream water was classified as good $(>20-40)$. The sodium percentage showed an increasing trend downstream, from 43.98 to 53.08, which was also within the desirable range. The stream water had a much better quality as far as $\mathrm{Na} \%$ is concerned; as the values of $\mathrm{Na}$ concentration were much lower (Table 2). These results indicate that plants irrigated with this water are not likely to be affected negatively, and the soils are not likely to become sodic because of high sodium levels [54,55]. The same pattern observed in $\mathrm{Na} \%$ was observed in the SAR values, which were all below 10 (Table 2) and deemed excellent for water use in crop irrigation according to Richards [19]. With an SAR value of 1.04 , the Khubelu stream is not likely to affect the salinity of the area where it is used for irrigation, as this value is excellent for irrigation waters according to Elsayed et al. [56]. According to Spandana et al. [57], a SAR below 5 shows no irrigation restriction.

Table 2. SAR, SSP, Na\%, and MAR for the wetland and stream.

\begin{tabular}{ccccc}
\hline Site & SAR & SSP & Na \% & MAR \\
\hline Upstream & 3.42 & 34.9 & 43.98 & 60.39 \\
\hline Midstream & 3.56 & 34.96 & 49.84 & 57.64 \\
\hline downstream & 4.62 & 39.25 & 53.08 & 57.32 \\
\hline Wetland & 3.83 & 36 & 46.59 & 63.14 \\
\hline Stream & 1.04 & 18.19 & 21.04 & 39.52 \\
\hline
\end{tabular}


The sodium Adsorption Ratio increased downstream of the wetland from 3.42 to 4.62 but decreased in the stream (1.04). These results showed that the wetland and stream water are not likely to affect the plants and soil which are irrigated with them.

The SSP values indicated that the water from the wetland contained higher amounts of soluble sodium compared to the water from the stream. The soluble sodium percentage values followed an increasing trend downstream of the wetland but were lower within the stream. All SSP values for both the stream and the wetland were below $50 \%$; therefore, according to Kumar et al. [58], the water would present no challenge for irrigation purposes. The MAR values for the wetland water were higher than 50 (Table 2) and categorized as unacceptable, whereas water in the stream had lower MAR values $(<50)$ and was acceptable for crop irrigation. These values showed that there is a magnesium hazard associated with the use of the wetland water for irrigation, whereas the stream water displays no such hazard $[59,60]$.

\subsection{Suitability of Water for Animal Consumption}

The maximum EC levels of $1.12 \mathrm{mS} / \mathrm{cm}(1.75 \mu \mathrm{S} / \mathrm{cm})$ and $2.11 \mathrm{mS} / \mathrm{cm}(3.29 \mu \mathrm{S} / \mathrm{cm})$ in the wetland and stream, respectively, were lower than the threshold value of $7800 \mu \mathrm{S} / \mathrm{cm} \mathrm{[38]}$ for animal consumption and classified as satisfactory according to FAO animal drinking water standards. Furthermore, there was no distinct trend in EC for water from upstream to downstream the wetland, with EC of the water from the midstream area being higher $(1.12 \mathrm{mS} / \mathrm{cm})$ than that of water from the other areas. Similarly, other animal drinking water standards such as TDS and Mg concentrations were below the limit of $3000 \mathrm{mg} / \mathrm{L}$ [39] and $500 \mathrm{mg} / \mathrm{L}$ [41], respectively, for consumption by some animals, posing no threat to these animals. Magnesium concentrations showed a decreasing trend in water from upstream to downstream the wetland, increasing to the maximum of $11.39 \mathrm{mg} / \mathrm{L}$ in the stream, which was below the allowable concentration of $500 \mathrm{mg} / \mathrm{L}$ for animal consumption. The study showed no specific trend in TDS across the wetland, being higher midstream $(352.13 \mathrm{mg} / \mathrm{L})$. The stream had the lowest TDS, with a mean of $151.6 \mathrm{mg} / \mathrm{L}$, and would pose no threat for animal consumption.

\subsection{Implication of Water Quality for the Use and Management of the Wetland}

The study showed that $\mathrm{EC}, \mathrm{DO}, \mathrm{PO}_{4}, \mathrm{BOD}$, and COD were accountable for poor water quality in the stream. Phosphate pollution was attributable to animal droppings and magnesium hazard, as the latter does not enable phosphate uptake by wetland vegetation. The stream would therefore be eutrophic, and its water unusable for various purposes. Water from eutrophic water systems is toxic and would be unsafe for domestic use and human consumption. Regulatory measures that would address this include the monitoring of external sources of carbonaceous and nitrogenous waste that deplete DO, subsequently increasing BOD and COD. Animal grazing has to be controlled as a regulatory measure regarding vegetation removal and excessive input of $\mathrm{PO}_{4}$.

Even though the stream water was suitable for animal drinking and crop irrigation, a magnesium hazard was reported in the study. A high concentration of magnesium could lower stream water quality by increasing water hardness, a condition which could also affect the bioavailability of nutrients like phosphates for crops irrigated by the water [61] Sources of magnesium have to be identified, followed by appropriate management programs to control the level of $\mathrm{Mg}$ in the wetland and stream. It is also recommended that frequent monitoring of the water quality of wetland and stream is implemented to check the effectiveness of the management program. This might lead to sustained crop production for downstream users.

\section{Conclusions}

This study showed that stream water from the wetland is classified as 'very poor', and may not be suitable for human consumption, but has a high potential for crop irrigation and livestock watering. The high WQI for the stream indicates that there might be no pollutant 
reduction from the wetland. This threatens the supply of purified water to users within the Orange-Senqu catchment, also putting them at risk of associated health challenges. The high WQI determined in the study is calling for stringent wetland management and conservation measures. While animal possession enhances communities' livelihoods economically, management practices should strive towards the control of stocking rates and of the grazing period and season (rotational grazing); other means of animal feeding and watering in order to reduce pressure from the animals should also be considered. This approach would address the magnesium hazard derived from wetland vegetation removal. Close identification and monitoring of activities that might add onto pollutants could form part of an informed decision-making process of wetland protection.

Declaring the wetland as a 'no-go area' during the dry season could also be one of the Best Management Practices (BMPs) ensuring that there will be enough time for wetland vegetation to recover. It is further recommended that, since this was a preliminary study, future studies should monitor the wetland water quality over a longer period in order to maintain a sustainable supply of clean water to the communities downstream of the catchment.

Author Contributions: Conceptualization, M.G., V.M.N.-J.; Methodology, M.G., V.M.N.-J.; validation, M.G. and V.M.N.-J.; software, V.M.N.-J.; formal analysis, M.G., V.M.N.-J.; investigation, M.G.; resources, M.G.; data curation, M.G.; writing—original draft preparation, M.G.; writing-review and editing, M.G. and V.M.N.-J.; visualization, M.G., V.M.N.-J.; supervision, V.M.N.-J. All authors have read and agreed to the published version of the manuscript.

Funding: This research received no external funding.

Institutional Review Board Statement: Not applicable.

Informed Consent Statement: Not applicable.

Data Availability Statement: The data that support the findings of this study are available on request from the corresponding author. The data are not publicly available due to privacy or ethical restrictions.

Conflicts of Interest: The authors declare no conflict of interest.

\section{References}

1. Amacha, N.; Karam, F.; Jerdil, M.; Frank, P.; Viala, E.; Hussein, D.; Kheireddin, S.; Baydoun, S. Assessment of the Efficiency of a Pilot Constructed Wetland on the Remediation of Water Quality; Case Study of Litani River, Lebanon. Environ. Pollut. Clim. Chang. 2017, 1, 119. [CrossRef]

2. Hammer, D.; Bastian, R. Constructed Wetland for Wastewater Treatment; Lewis Publishers: Chattanooga, TN, USA, 1988.

3. Mekiso, F. Hydrological Processes, Chemical Variability, and Multiple Isotopes Tracing of Water Flow Paths in the Kudumela WetlandLimpopo Province; Rhodes University: Grahamstown, South Africa, 2011.

4. Thorslund, J.; Jarsjö, J.; Jaramillo, F.; Jawitz, J.W.; Manzoni, S.; Basu, N.B.; Chalov, S.R.; Cohen, M.J.; Creed, I.F.; Goldenbrg, R.; et al. Wetlands as large-scale nature-based solutions: Status and challenges for research, engineering and management. Ecol. Eng. 2017, 108, 489-497. [CrossRef]

5. Seelig, B.; DeKeyser, S. Water Quality and Wetland Function in the Northern Prairie Pothole Region; NDSU Extension Services: North Dakota State University: Fargo, ND, USA, 2006.

6. Mereta, S. Water Quality and Ecological Assessment of Natural Wetlands in Southwest Ethiopia. Ph.D. Thesis, Ghent University, Ghent, Belgium, 2013.

7. Wang, B.; Wang, Y.; Wang, W. Retention and mitigation of metals in sediment, soil, water, and plant of a newly constructed root-channel wetland (China) from slightly polluted source water. Springer Plus 2014, 3, 3-26. [CrossRef]

8. Zhang, Y.; Wang, L.; Hu, Y.; Xi, X.; Tang, Y.; Chen, J.; Fu, X.; Sun, Y. Water Organic Pollution and Eutrophication Influence Soil Microbial Processes, Increasing Soil Respiration of Estuarine Wetlands: Site Study in Jiuduansha Wetland. PLoS ONE 2015, 10, e0126951. [CrossRef]

9. Gabor, T.S.; Murkin, H.R.; Stainton, M.P.; Boughen, J.A.; Titman, R.D. Nutrient additions to wetlands in the Interlake region of Manitoba, Canada: Effects of a single pulse addition in spring. Hydrobiology 1994, 279, 497-510. [CrossRef]

10. Guntenspergen, G.; Peterson, S.; Leibowitz, S.; Cowardin, L. Indicators of wetland conditions for the Prairie Pothole region of the United States. Environ. Monit. Assess. 2002, 78, 229-252. [CrossRef]

11. GoL. Lesotho Water and Sanitation Policy; Ministry of Natural Resources: Maseru, Lesotho, 2007.

12. Pesce, S.; Wunderlin, D. Use of water quality indices to verify the impact of Córdoba City (Argentina) on Suquìa River. Water Res. 2000, 34, 2915-2926. [CrossRef] 
13. Nemati, V.; Mirghafarry, N.; Ebrahimi, E.; Safianian, A. Water quality assessment in an arid region using a water quality index. Water Sci. Technol. 2009, 60, 2319-2327.

14. Chauhan, A.; Singh, S. Evaluation of Ganga water for drinking purpose by water quality index at Rishikesh, Uttarakhand, India. Rep. Opin. 2010, 2, 53-61.

15. Chowdhury, R.; Muntasir, S.; Hossain, M. Water quality index of water bodies along Faridpur-Barisal road in Bangladesh. Glob. Eng. Technol. Rev. 2012, 2,1-8.

16. Oişte, A.; Breabăn, I. Water quality index for Rediu, Cacaina and Ciric river in urban area of Iasi city. Present Environ. Sustain. Dev. 2012, 6, 429-437.

17. Swamee, P.; Tyagi, A. Improved method for aggregation of water quality subindices. J. Environ. Eng. 2007, 133, 220-225. [CrossRef]

18. Akoteyon, I.; Omotayo, A.; Soladoye, O.; Olaoye, H. Determination of water quality index and suitability of urban river for municipal water supply in Lagos-Nigeria. Eur. J. Sci. Res. 2011, 52, 263-271.

19. Richards, L.A. Diagnosis and Improvement of Saline and Alkali Soils; Department of Agriculture: Washington, DC, USA, 1954.

20. Suarez, D.; Wood, J.; Lesch, S. Effect of SAR on water infiltration under a sequential rain-irrigation management system. Agric. Water Manag. 2006, 86, 150-164. [CrossRef]

21. Meireles, A.C.M.; de Andrade, E.M.; Chaves, L.C.G.; Crisostomo, L.A. A new proposal of the classification of irrigation water. Rev. Ciênc. Agron. 2010, 41, 349-357. [CrossRef]

22. LMS. 2019. Available online: https://www.lesmet.org.ls/home/open/climate-of-Lesotho (accessed on 4 April 2021).

23. DWA. Lesotho National Wetlands Management Programme; Government of Lesotho: Maseru, Lesotho, 2005.

24. Kotze, D.; O'Connor, T. Vegetation variation within and among palustrine wetlands along an altitudinal gradient in KwaZuluNatal. Plant Ecol. 2000, 146, 77-96. [CrossRef]

25. APHA. Standard Methods for the Examination of Water and Wastewater, 21st ed.; American Public Health Association: Washington, DC, USA, 2005.

26. Bharti, N.; Katyal, D. Water quality indices used for surface water vulnerability assessment. Int. J. Environ. Sci. 2011, 2, 154-173.

27. Akter, T.; Jhohura, F.T.; Akter, F.; Chowdhury, T.R.; Mistry, S.K.; Dey, D.; Barua, M.K.; Kanti; Islam, A.; Rahman, M. Water Quality Index for measuring drinking water quality in rural Bangladesh: A cross-sectional study. J. Health Popul. Nutr. 2016, 35, 4. [CrossRef] [PubMed]

28. Fathi, P.; Ebrahim, E.; Mirghafarry, M.; Esmaeili, O.A. Water quality assessment in Choghakhor Wetland using WQI. Iran. J. Fish Sci. 2016, 15, 508-523.

29. Ranells, N.N.; Green, J.T.; Poore, M.H.; Hansard, R.; Young, J. Grazing Livestock and Water Quality; North Carolina Cooperative Extension Service: Charlotte, NC, USA, 2001.

30. Wen, Y.; Schoups, G.; van de Giesen, N. Organic pollution of rivers: Combined threats of urbanisation, livestock farming and global climate change. Sci. Rep. 2017, 7, 43289. [CrossRef]

31. Soldan, M.; Sirotiak, M.; Bartosova, A. Comparison of Two Spectrophotometric Technique for Nutrients in Water Samples; University of Technology, Faculty of Material Science and Technology: Bratislava, Slovakia, 2012.

32. Curtis, C. Oregon Water Quality Index a Tool for Evaluating Water Quality Management Effectiveness. J. Am. Water Resour. Assoc. 2001, 37, 125-137.

33. Pathak, S.K.; Shambhu, P.P.; Pathak, T. Determination of water quality index river Bhagirathi in Uttarkashi, Uttarakhand India. Int. J. Res. Granthaalayah 2015, 3, 1-7. [CrossRef]

34. Mishra, P.; Patel, R. Study of the pollution in the drinking water of Rairangpur, a small tribal dominated town of North Orissa Indian J. Environ. Ecoplan. 2001, 5, 293-298.

35. Todd, D. Groundwater Hydrology, 3rd ed.; John Wiley \& Sons: Hoboken, NJ, USA, 1995.

36. Paliwal, K. Irrigation with Saline Water, Monogram No. 2 (Newseries); IARI: New Delhi, India, 1972.

37. Raghunath, H. Groundwater, 2nd ed.; Wiley Eastern Ltd.: New Delhi, India, 1987.

38. Curran, G. Water for Livestock: Interpreting Water Quality Tests; NSW Government: Broken Hill, Australia, 2014.

39. Meehan, M.; Stokka, G.; Mostrom, M. Livestock Water Quality; NDSU: Fargo, ND, USA, 2021.

40. DWAF. South African Water Quality Guidelines: Agricltural Use: Irrigation; Department of Water Affairs and Forestry: Pretoria, South Africa, 1996.

41. FAO. Guidelines: Land Evaluation for Irrigated Agriculture-FAO Soils Bulletin 55; FAO of the United Nations: Rome, Italy, 1985.

42. Kistemann, T.; Claßen, T.; Koch, C.; Dangendorf, F.; Fischeder, R.; Gebel, J.; Vacata, V.; Exner, M. Microbial of drinking water reservoir tributaries during extreme rainfall and runoff. Appl. Environ. Microbiol. 2002, 68, 2188-2197. [CrossRef]

43. Kato, T.; Kuroda, H.; Nakasone, H. Runoff characteristics of nutrients from an agricultural watershed with intensive livestock production. J. Hydrol. 2009, 368, 79-87. [CrossRef]

44. Troyer, N.; Mereta, S.; Goethals, P.; Boets, P. Water Quality Assessment of Streams and Wetlands in a fast Growing East African City. Water 2016, 8, 123. [CrossRef]

45. Mason, A.; Xu, Y.; Saska, P.; Viosca, A. Streamflow and Nutrient Dependence of Temperature Effects on Dissolved Oxygen in Low-Order Forest Streams; ASABE: Austin, TX, USA, 2007; pp. 374-380.

46. Oyem, H.; Oyem, I.; Ezeweali, D. Temperature, pH, Electrical Conductivity, Total Dissolved Solids and Chemical Oxygen Demand of Groundwater in Boji-Boji Agbor Area and Immediate Suburbs. Res. J. Environ. Sci. 2014, 8, 444-450. [CrossRef] 
47. Richardson, C.; Marshall, P. Processes controlling movement, storage and export of phosphorus in a fen peatland. Ecol. Monogr. 1986, 56, 279-302. [CrossRef]

48. Mots'ets'e, M.; Mapeshoane, B.E.; Masopha, M.; Khoeli, M.B.; Nkheloane, T.; Mokhatla, M.; Rasekoele, M.G. Characterising wetland hydrology and water quality in streams and wetlands of Khalong-la-Lithunya, Lesotho. Afr. J. Rural Dev. 2017, 2, 117-125.

49. Muigai, P.; Shiundu, P.; Mwaura, F.; Kamau, G. Correlation between Dissolved Oxygen and Total Dissolved Solids and their Role in the Eutrophication of Nairobi Dam, Kenya. Int. J. BioChemiPhysics 2010, 18, 38-46.

50. Carpenter, S. Phosphorus control is critical to mitigating eutrophication. Proc. Natl. Acad. Sci. USA 2008, 105, 11039-11040. [CrossRef]

51. Hubbard, R.; Newton, G.; Hill, G. Water quality and the grazing animal. J. Anim. Sci. 2004, 84, $255-263$.

52. Riddle, M.; Bergstrőm, L. Phosphorus Leaching from Two Soils with Catch Crops Exposed to Freeze-Thaw Cycles. Agron. Soils Environ. Qual. 2013, 105, 803-811. [CrossRef]

53. Simsek, C.; Gunduz, O. IWQ index: A GIS-integrated technique to assess irrigation water quality. Environ. Monit. Assess. 2007, 128, 277-300. [CrossRef] [PubMed]

54. Purushothman, P.; Rao, M.S.; Kumar, B.; Rawat, Y.S.; Krishan, G.; Guptar, S.; Marwah, S.; Bhatia, A.K.; Kaushik, Y.B.; Angurala, M.P.; et al. Drinking and Irrigation Water Quality in Jalandhar and Kapurthala districts, Punjab, India: Using Hydrochemistry. Int. J. Earth Sci. Eng. 2012, 5, 1599-1608.

55. Sundaray, S.; Nayak, B.; Bhatta, D. Environmental studies on river water quality with reference to suitability for agricultural purposes: Mahanadi river estuarine system, India-A case study. Environ. Monit. Assess. 2008, 155, 227-243. [CrossRef] [PubMed]

56. Elsayed, S.; Hussein, H.; Moghanm, F.S.; Khdher, K.M.; Eid, E.M.; Gad, M. Application of Irrigation Water Quality Indices and Multivariate Statistical Techniques for Surface Water Quality Assessments in the Northern Nile Delta, Egypt. Water 2020, 12, 3300. [CrossRef]

57. Spandana, M.; Suresh, K.; Prathima, B. Developing an Irrigation Water Quality Index for Vrishabavathi Command Area. Int. J. Eng. Res. Technol. 2013, 2, 821-830.

58. Kumar, P.; Kumar, S.A.; Pradeep, T.; Suresh, M.; Ramesh, S. Assessment of the Groundwater Quality for Irrigation Purposes in Rasipuram Taluk, Tamilnadu, India. Asian J. Res. Soc. Sci. Humanit. 2016, 6, 547-553. [CrossRef]

59. Tiri, A.; Belkhiri, L.; Asma, M.; Mouni, L. Suitability and Assessment of Surface Water for Irrigation Purpose. In Water Chemistry IntechOpen: London, UK, 2019; pp. 1-18.

60. Abdel-Fattah, M.; Abd-Elmabod, S.K.; Aldosari, A.A.; Elrys, A.S.; Mohamed, E.S. Multivariate Analysis for Assessing Irrigation Water Quality: A Case Study of the Bahr Mouise Canal, Eastern Nile Delta. Water 2020, 12, 2537. [CrossRef]

61. Qadir, M.; Schubert, S.; Oster, J.D.; Sposito, G.; Minhas, P.S.; Cheraghi, S.A.M.; Murtaza, G.; Mirzabaev, A.; Saqib, M. Highmagnesium waters and soils: Emerging environmental and food security constraints. Sci. Total Environ. 2018, 642, $1108-1117$. [CrossRef] [PubMed] 